\title{
Pulmonary valve replacement after correction of Tetralogy of Fallot
}

\author{
R Meza*, C Obando, R Breciani, N Sandoval \\ From 23rd World Congress of the World Society of Cardio-Thoracic Surgeons \\ Split, Croatia. 12-15 September 2013
}

\section{Background}

The Tetralogy of Fallot (TOF) is a frequent cardiopathy in our days, corresponding to $7 \%$ of the congenital cardiopathies.

However it is acknowledged that one of the main causes of reintervention in these patients is the presence right ventricular failure secondary to pulmonary valve insufficiency (IP) leading the patient to intolerance to exercise, ventricular tachycardia and sudden death. The aim of our investigation is describing our experience of those patients subjected to (TOF) correction who have required a pulmonary valve replacement.

\section{Methods and results}

Between January 1996 and December 2011252 individuals with Tetralogy of Fallot (TOF) were intervened. Of these, 10 patients $(3,9 \%)$ required replacement of pulmonary valve ( 5 men and 5 women).

The patients' average age was 9, $3 \pm 3$, 9 years.

The average time interval between the (TOF) correction and the replacement of pulmonary valve was 7, $2 \pm$ 3,5 years.

The main indication for replacement of pulmonary valve was right cardiac failure $50 \%(5 / 10)$.

We used Contegra graft in 20\% (2/10) patients, allograft in 40\% (4/10) patients, bioprosthesis in 40\% (4/10) patients.

As concomitant corrected procedures during the pulmonary valve replacement $30 \%(3 / 10)$ patients with residual interventricular communication and tricuspid valve repair in $40 \%(4 / 10)$ patients.

The average aortic clamping time was of $119.4 \pm 62.5$ minutes.

The average ICU stay was $3.5 \pm 1,5$ days.

\footnotetext{
* Correspondence: rafameza77@hotmail.com

Congenital Heart Surgery, Fundacion Cardioinfantil, Bogota, Colombia
}

An early mortality was present $10 \%$ (1 patient) and no one presented late mortality.

In the postoperative echocardiographic controls was found a decrease of the right ventricle diameter $31,4 \pm 7,9$ vs $27,8 \pm 4,8$ and improvement of the ventricular function $69,9 \pm 11,1 \%$ vs $72,2 \pm 12 \%$

\section{Conclusion}

The pulmonary valve replacement after correction of (TOF) significantly improves the function of the right ventricle. It is a safe procedure conducted with a low mortality rate.

Published: 11 September 2013

doi:10.1186/1749-8090-8-S1-P176

Cite this article as: Meza et al.: Pulmonary valve replacement after correction of Tetralogy of Fallot. Journal of Cardiothoracic Surgery 20138 (Suppl 1):P176.
Submit your next manuscript to BioMed Central and take full advantage of:

- Convenient online submission

- Thorough peer review

- No space constraints or color figure charges

- Immediate publication on acceptance

- Inclusion in PubMed, CAS, Scopus and Google Scholar

- Research which is freely available for redistribution
() Biomed Central

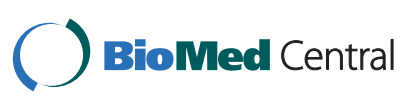

(c) 2013 Meza et al; licensee BioMed Central Ltd. This is an Open Access article distributed under the terms of the Creative Commons Attribution License (http://creativecommons.org/licenses/by/2.0), which permits unrestricted use, distribution, and reproduction in any medium, provided the original work is properly cited. 